\title{
National Information Systems for Science and Technique - The Implementation of the SYNAT Project
}

\author{
Jerzy Kisielnicki \\ Faculty of Management, Warsaw University, Warsaw, Poland \\ jerzy@kisielnicki.edu.pl
}

\begin{abstract}
The article discusses the role of national information systems for science and technique based on the example of the implementation of the SYNAT (System for Science and Technique) project in the development of the system of supplying content to education. This is so as new publications and scholarly reports come into being every day. To be able to teach, universities must possess up-to-date information and knowledge. It is an opportunity to obtain the highest possible quality level of education they provide.

The development of a national information system for science and technique is recommended. The system being an element of the global network can reduce the gap in the absorption of the latest scientific achievements in countries which do not possess the adequate ICT infrastructure. The implementation of the concept of open science, i.e. Open Access (OA) is highlighted. The implementation of this concept favors the development of science as well as the processes of a more complete use of unique scientific equipment. It is also conducive to the development of individual researchers and research teams.

In the final part of the article proposals for strategic organizational solutions in the field are recommended. The suggested solutions are based on the analysis of the strategies' dependencies on two variables, namely the system of coordination, i.e. a management system and a financial solution. The two variables have been selected as the ones which have the biggest impact on the choice of the organizational form and a way of funding the project.
\end{abstract}

The article also outlines a collection of issues that require further research.

Keywords: SYNAT, National Information Systems, project management, content management, Systems of Education, information society, knowledge management

Material published as part of this publication, either on-line or in print, is copyrighted by the Informing Science Institute. Permission to make digital or paper copy of part or all of these works for personal or classroom use is granted without fee provided that the copies are not made or distributed for profit or commercial advantage AND that copies 1) bear this notice in full and 2) give the full citation on the first page. It is permissible to abstract these works so long as credit is given. To copy in all other cases or to republish or to post on a server or to redistribute to lists requires specific permission and payment of a fee. Contact Publisher@,InformingScience.org to request redistribution permission.

\section{On the Need to Create National Information Systems for Science and Technique}

Current systems of education, especially postgraduate and doctoral ones, need to be constantly supplied with and updated by contemporary knowledge as new publications and scientific reports are 
published every day. To be able to teach, universities must have up-to-date information and knowledge. This is an opportunity to achieve the highest possible quality of education. At the same time, as we will show later, even in Europe (not to speak about other parts of the world like Asia, Africa and South America) there are big differences in how scholarly institutions are equipped in the infrastructure necessary to do scientific research. It is similar with the unequal deployment of scholarly personnel. How can this be changed? Each country's ambitions are very high. Each country wishes to have a system of education that can compete against the most developed countries in the world. As a result, the economy and the system of education will be modern and competitive. But do we have adequate ICT means to achieve this goal? And if we have them, do the existing procedures support their effective and successful use?

In literature, many gauges are proposed to make such an assessment. One of them is the analysis of the position of a particular country's universities in the international ranking of the best universities in the world. As the example of Poland is analyzed more thoroughly here, we can state that this position is not very high. Poland, which is in the middle position in the world in terms of economic and social indicators, has only two universities placed between the $300^{\text {th }}$ and $500^{\text {th }}$ position in the world ranking. The position of a country in the world is determined by credible synthetic indicators that are calculated based on reliable sources. Research done by the World Economic Forum together with INSEAD is especially interesting and supported by scholarly authorities. The position of a country in this kind of research is assessed based on the Networked Readiness Index (NRI). There are many different definitions of the NRI in the publications, e.g. "network readiness indicator", "internet potential" and "readiness to transform on the way to information society". The index evaluates a country's readiness to exploit the opportunities offered by ICT. In terms of the NRI, Poland has been classified on the $65^{\text {th }}$ position among the total of 133 countries under examination. The reports on the analyzed measurements are published annually. Thus, the NRI is a composite of 68 data grouped in three main components:

- the environment index: market, political and regulatory, infrastructure environment;

- the readiness index: readiness of individuals, businesses and public administration;

- the usage index: usage by individuals, businesses and public administration.

Out of the 68 analyzed data, 27 can be defined as the so-called hard - quantitative ones. They were created by reputable international institutions, e.g. the United Nations, the World Bank or the International Telecommunication Union. Other data come from surveys commissioned by the World Economic Forum. Table 1 presents the European countries (in column one in the brackets next to the NRI values, there are positions of the countries in the world ranking). The table presents only the European Union countries' indicators of the broadband Internet access in descending order (middle column). Access to the Internet is one of the leading indicators of the transfer of science to the system of education. The fourth column shows a relatively wide spectrum of the analysis of the Internet access at workplace. The examined employees were those who use the Internet at least once a week. However, independent contractors (freelancers) are not included in this category.

Contemporary ICT enables developing countries to bridge the gap between them and the developed countries in building the communications infrastructure of the scientific research system that supplies content to the system of education. The current delays will probably not be completely eliminated but they will surely be weakened. The use of the stores of knowledge depends not only on the possession of hardware. Information and knowledge bases are decisive, since they are supplied by scientific information systems of the best world-class organizations.

Based on the example of my participation in and management of the research team working on a strategic program devoted to building a national information system for science and technique, I 
would like to present the activities that are carried out in this field. The program that is called SYNAT (in Polish: SYstem Informacji NAukowo Technicznej, i.e. Information System for Science and Technique) (Kisielnicki, 2011; Niezgódka, 2009) aims to create in Poland a universal, open, repository hosting and communications platform for network stores of knowledge for science, education and open knowledge society that will be linked to the adequate solutions worldwide. SYNAT is supposed to be the basis of the national information system for science and technique. The project that is financed by the National Center of Research and Development with the use of the state budget funds is implemented by seventeen scholarly institutions. Within that project, the author of the article manages the building of a long-term funding model that is to guarantee the durability of the information system for science and technique. One of the tasks of the undertaken activities is to propose solutions for supplying educational systems with information and knowledge and the role of the state budget as the administrator of the information systems for science and technique.

Table 1.Europe in terms of the possessed ICT resources (Source: Dutta, 2010)

\begin{tabular}{|l|l|l|l|}
\hline Country & $\begin{array}{l}\text { The NRI volume } \\
\text { The number in brackets } \\
\text { is the country's position } \\
\text { in the world ranking }\end{array}$ & $\begin{array}{l}\text { Broadband access to the } \\
\text { Internet in 2009, \% }\end{array}$ & $\begin{array}{l}\text { Employees using a com- } \\
\text { puter with the Internet ac- } \\
\text { cess in their workplace in } \\
\text { 2009, \% (minimum once a } \\
\text { week) }\end{array}$ \\
\hline Finland & $5,44(6)$ & 85 & 62 \\
Spain & $4,37(34)$ & 85 & 40 \\
Malta & $4,75(26)$ & 85 & No data \\
France & $4,99(18)$ & 84 & 40 \\
Belgium & $4,86(22)$ & 83 & 50 \\
Sweden & $5,65(1)$ & 83 & 58 \\
Norway & $5,22(10)$ & 83 & 60 \\
Germany & $5,16(14)$ & 83 & 45 \\
Luxemburg & $5,02(17)$ & 82 & 41 \\
Estonia & $4,81(25)$ & 82 & 55 \\
Holland & $5,32(9)$ & 82 & 53 \\
Great Britain & $5,17(13)$ & 82 & 45 \\
Slovenia & $4,51(31)$ & 82 & 32 \\
Italy & $3,97(48)$ & 81 & 32 \\
Portugal & $4,41(33)$ & 81 & 28 \\
Cyprus & $4,48(32)$ & 81 & 32 \\
Greece & $3,82(56)$ & 80 & 65 \\
Denmark & $5,54(3)$ & 80 & $64(2008)$ \\
Slovakia & $3,86(55)$ & 78 & 31 \\
Czech Republic & $4,35(36)$ & 76 & 38 \\
Ireland & $4,82(24)$ & 74 & 42 \\
Austria & $4,94(20)$ & 72 & 42 \\
Hungary & $3,98(46)$ & 70 & No data \\
Croatia & $3,91(51)$ & 65 & 35 \\
Bulgaria & $3,66(71)$ & 64 & 23 \\
Latvia & $3,90(52)$ & 58 & 25 \\
Poland & $3,74(65)$ & 40 & 22 \\
Lithuania & $4,12(41)$ & & \\
Romania & $3,80(59)$ & & \\
\hline
\end{tabular}

The article aims to justify and present the characteristics of the proposed organizational solutions in the field of the system of this class that is supposed to provide supplies for the system of education. The presentation takes into account the ideas included in the postulates of the so-called Open Access (OA). The research in this field is continued. The article presents the stage of the 
research concerning the proposals of organizational solutions. The stage is a proverbial milestone in the implementation of the SYNAT project.

\section{On the Building of the National Repository Hosting and Communications Platform for the Stores of Knowledge for Science, Education, and Open Knowledge Society}

Institutional repositories are defined by R. Crow (2002) as digital collections that capture, preserve and disseminate intellectual output of scholarly communities of one or several universities. They are more and more commonly entering university structures, changing the paradigm of communications in science at the same time. The content of the repositories is defined by the institutions; it has a scientific, cumulative and perpetual character, it is available within the Open Access, and it is interoperable. We can observe an enormous increase in the number of repositories existing worldwide as well as publications on this subject. It refers especially to guidebooks describing the process of developing digital archives (Barton, 2004; Gibbons, 2004). Scholarly material contained in them includes scientific articles, scientific research results (reviewed or not, published or not) and M.A. theses or doctoral dissertations in an electronic form. Sometimes repositories contain typical administrative documents, thematic notes or other teaching material.

Institutional repositories are network servers which enable parallel (to paper-based) on-line publication and long-term archiving and dissemination to authorized circles of users (e.g. scholars, university students, members of a professional association, etc.) or broader community without discrimination and unnecessary limitations. Such repositories also provide authors with legal advice on methods and scope of protecting their rights.

In general, we deal with three entities taking part in the process of using scholarly repositories: authors (production), users (consumption) and a service platform (distribution). Graph 1 illustrates relations between those entities:

It is estimated that 24 thousand scholarly journals are published worldwide (Björk, Roos, \& Lauri, 2009). This enormous scholarly potential requires dissemination to the broadest possible circle of users. For years, world publications have been drawing attention to the necessity to disseminate this great intellectual capital (Castells, 1996; Soete, Weel, 2005; Tansey, 2003; Arlt, 2006). It is one of the decisive factors in the process of developing an open society or information society (Köhler, Arndt, Fetzer, 2008; Safar \& Mahdi, 2012; Papadopoulou, Kanellis, Martakos, 2011). How is this great scientific potential going to supply the system of education with content? In our opinion, the goal can be achieved by creating a national commonly accessible information system for science and technique. Its implementation requires considerable financial outlays. We can list the following elements constituting the cost of such a commonly accessible system implementation: 


\section{Graph 1. Model of supplying repositories with information and disseminating it,} e.g., in SYNAT (Source: Author's own output)

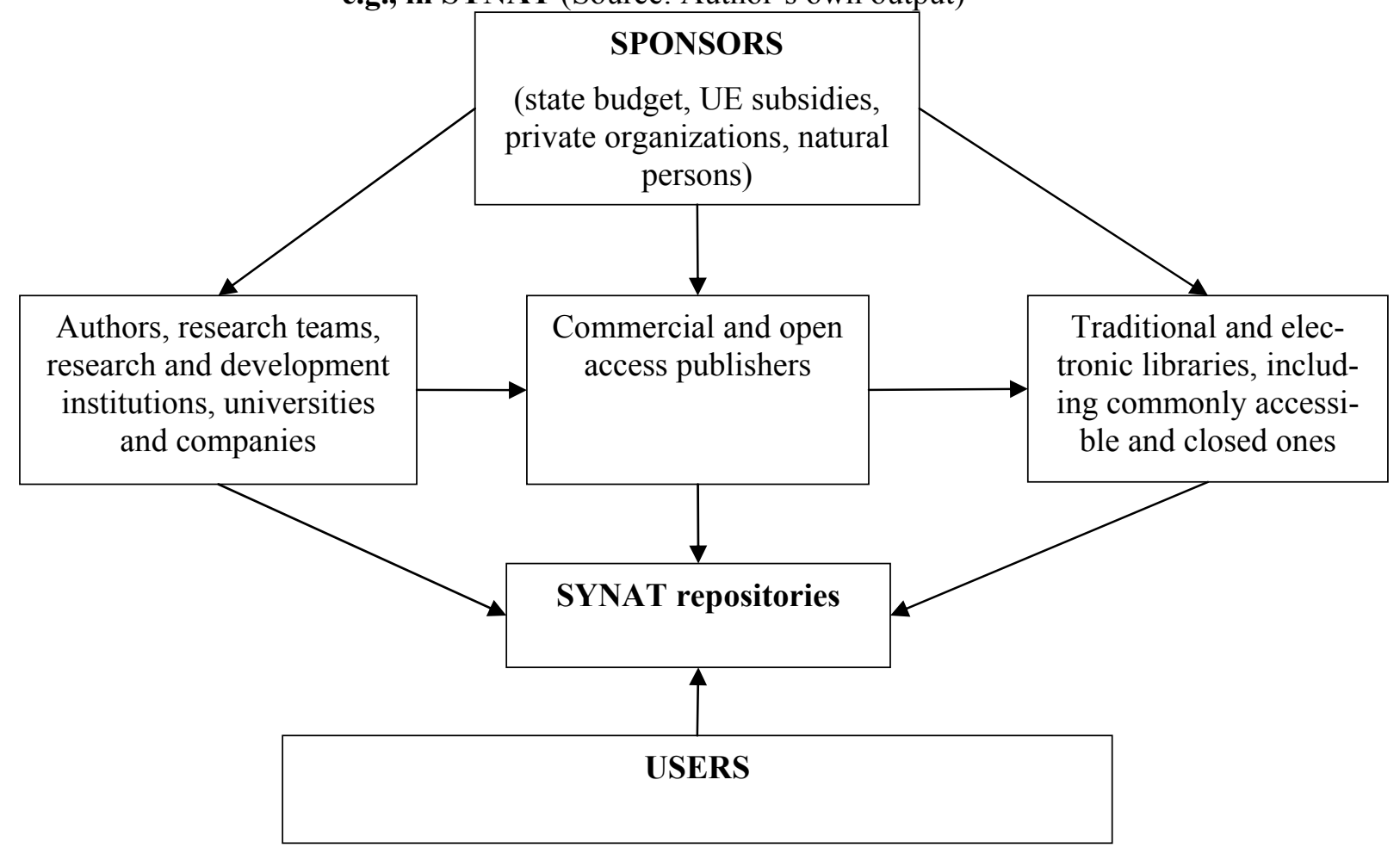

Outlays on the system contents. It accounts to $50 \%$ of the total expenditures incurred within the information system for science and technique.

1. Outlays on the absorption of stores in the adequate databases and knowledge bases (e.g. digitalization, new documents development).

2. Outlays on the development of the infrastructure, including communications network and access points to the possessed stores of information and knowledge.

3. Outlays on the system exploitation; both on people and software and hardware means. These include appropriate license purchase and copyright-related costs. This group of costs results from the increase in fees for bases, services, platforms etc. It depends on a product market value and the size of the ordering institution measured against the number of employees and students (full time equivalent). In general, fees do not depend on the use intensity (number of sessions or access length).

The incurred outlays make it possible to develop the national information system for science and technique that can play a significant role in the creation of information society based on knowledge management. This will result in the increase in the intellectual capital of individual corporations as well as the whole country.

The detailed effects achieved are as follows:

1. Increase in the scholarly level of a university or institution involved in that activity.

2. Provision of scholarly communication between individual domestic and international organizations.

3. Popularization of scholarly achievements on international forums. 
4. Profits obtained from commercialization of selected activities (services, patents, license sales).

5. Reduction of losses resulting from double or triple cost incurrence on the same kind of research.

6. Strengthening the activities of the consultancies involved in the transfer of science to the economy, i.e. the increase in the innovation of the economy.

Quantitative calculation of costs and effects is difficult. It is due to various reasons, including the lack of a method to calculate the cost of developing non-material goods such as any kind of intellectual work. The mechanisms for producing added value are also complex; there, an extensive link between the contents and the system of consultancies and other firms involved in transferring scientific research to the economy takes place.

Contemporary development of ICT makes the cost of providing service to one client get close to nil. With a rapid development of the web technologies we can expect further improvement of such free of charge tools as CiteSeer or a little newer but rapidly growing Google Scholar, or finally Microsoft Academy gaining more and more supporters. We can derive patterns from the achievements of Open Source Software and business models created around it, including those combining free and commercial software. The cost results from legal regulations which either are an outcome of economic models or create them. The contemporary progress in technique and technology, including broader use of cloud computing, can totally change economic calculations and the proposed organizational solutions. It is more and more difficult to identify every device owner in a 'cloud' who takes part in the implementation of our project. In the world information practice, the significant part of the cost is the purchase of the right to use the chargeable database resources.

\section{National Information System for Science and Technique, Its Elements and Functions}

The basic source for supplying the educational system with content is a national information system for science and technique. It is linked to other similar systems in the world. As far as Poland is concerned, it is the link with the European Union countries, although there is also a strong connection with the systems in the USA, Japan and Canada. With the use of a computer network, it forms one whole from these system elements which are related to the issues of scientific and technical information and its application.

The national information system for science and technique is characterized by the following formula:

$$
\mathrm{KSINT}=\{\mathrm{P}, \mathrm{I}, \mathrm{T}, \mathrm{O}, \mathrm{M}, \mathrm{Z}, \mathrm{R}\}
$$

Where:

KSINT - a national information system for science and technique which provides services for all entities on the territory of a country and is responsible for generating, processing, storing and disseminating scientific and technical information and its derivatives independent of the organizational and legal forms;

$\mathrm{P}$ - a collection of entities which are passive and active users of the system; most often these are universities, institutes, corporations, businesses, hospitals, etc.;

I - a collection of information resources related to science and its application. These include open resources of libraries and scholarly institutions, commercial scholarly stores, 
stores of digital libraries, economic and technical information, university teaching materials, including e-learning stores;

T- a collection of technical means which constitute the management infrastructure. This is a part that depends on a rapid scientific and technical development, including the above-mentioned web technologies and cloud computing;

$\mathrm{S}$ - a management formula, i.e. the adopted organizational model and the role of the state budget and private institutions in it;

$\mathrm{M}$ - a collection of meta-information, i.e. information about scientific and technical information;

$\mathrm{Z}$ - a collection of para-information, i.e. information about sources of formerlymentioned information;

$\mathrm{R}$ - a collection of relations that take place between formerly mentioned elements of the information system for science and technique.

One of the basic tasks of the national information system for science and technique is to increase the quality of scientific research and the supply of the newest knowledge for the system of education. The use of ICT in the process of education is becoming more and more essential. Learning tools are created based on the methodology of learning objects, which is more and more important in the field of e-learning. The main idea of the above-mentioned methodology is a possibility to define and create knowledge components and then group them in learning objects. They are stored in databases and described by educational meta-data. Such a structure creates conditions for sharing learning objects and putting them together in order to develop a lecture or a course.

What are the relations between the national system and SYNAT that is being developed? SYNAT, as it was mentioned, is supposed to be the nucleus of a national information system for science and technique. It is one of the most important stages of developing a coherent domestic system. A national information system for science and technique is a concept describing the strategic directions of the state actions rather than a system functioning in the real world. As far as SYNAT is concerned, we know its range, there are implementers and there are means necessary to implement it. Of course, there are elements of a national information system for science and technique such as scientific and public libraries, universities' and institutes' systems, etc. But is it a coherent system? We can doubt. KSINT is a term we use to show a direction of activities in order to develop the existing national information system for science and technique. In its destination layer, the system should make the systems of education be constantly supplied with the newest knowledge based on scientific research. Such a target national information system for science and technique can also be defined as a multi-level structure. It enables the users of the system to transform information from the field of science and scientific and technical progress into desired exit information through the use of adequate procedures and models. KSINT can also be defined as a sub-system of a countrywide information system within which we deal with: an organized collection of people (authors and their collaborators), processing procedures, bases of data, models and knowledge, and devices used to provide the members of the public with information in the field of science and its application which they are interested in. Similarly, although in connection with the management information system, E. Turban (1999) writes: "Management Information System is a formal computer system, built to prove, select and integrate information obtained from many different sources in order to guarantee up-to-date information necessary for decision-making in management”.

Systems of education require a constant supply of information, especially in the field of scientific achievements. Information obtained during multi-layer communication is treated as a specific intellectual store of knowledge of individual organizations and a particular country's economy. 
Possession of this information makes it possible to provide supplies for educational processes. There has been a 15-fold increase in the number of communications network nodes in the last 10 years (Laudon \& Traver, 2011). In this space, the time of information transfer, as well as the duration of a decision making process, is very short and is limited to fractions of a second.

Scientific repositories fulfill a range of functions, e.g. they register the acknowledgement of a particular work's authorship, certify the work as scientific or technical information, select and verify the quality of the work, disseminate it, archive it for the prospective users, microfilm it etc. (Szpringer, 2011).

Open access strategies aim at reconfiguration of cost burdens: from end users towards the entities providing works (universities, libraries and authors themselves).

\section{Proposals for the Organization of a National Information System for Science and Technique Exploitation}

An organization propagating a strategy of open science is a dominating concept in some circles. The term "open" means commonly accessible. Scientific and research organizations do research in cooperation with independent partners who are located all over the world. The approach of open (common) science that in literature is called Open Access is conducive to the development of science and the processes of a more complete use of the unique scientific equipment. It is also favorable to individual scholars' or research teams' development. Open Access (OA) is defined as a free, common, durable and immediate one (Weber, 2004; Suber, 2007). As a result, every user has access to digital forms of recording data and scientific or educational contents. The development of the Internet and a quasi-monopolistic market position of editors, who dictate prices and limit access to scientific, educational and cultural publications, as well as more and more limited budget possibilities of public institutions responsible for popularization of the results of scientific research and cultural output constitute the key reasons for the OA initiative to come into being (Szpringer, 2011).

A concept of OA is strictly connected with the scholarly movement called Open Access Movement, which has been developing since the 1990s and acts for the development of a new, open model of scholarly communications. Around the concept of open access, there are many initiatives which support and promote this idea. The main communications channels used to distribute knowledge in the Open Access model are open journals and repositories. It is necessary to remember that the term 'repositories' first of all refers to storage places, not places providing access. As a result, activities connected with OA are conducive to treating scientific research as a social process. Scientific results and achievements become a basis for gaining prestige by individual scholars and organizations they work for. Most countries' legal systems regarding the assessment of universities and scientific institutions (including the so-called parametrization) emphasize the openness of publications. Most scholarly institutions' strategies concentrate on the creation of conditions for publications and making them available. Open Access issues in its different dimensions are the subject matter of a worldwide discussion. It is conducted in many circles, especially in institutions that finance scholarly research and at universities. In the time of economic crisis individual governments show interest in open access. Financial resources are limited and there are doubts whether scholarly research financed from public funds is addressed to the appropriate beneficiaries. There is also a fear that public funds can be wasted as a result of multiple payments for research (first for doing the research, next for obtaining access to the results, finally there is a possibility of doubling it).

Open Access activities are connected with the Open Source movement and can be associated not only with open science, but also with other actions such as open software, open standards and open research. The term 'open' is not the same as 'free of charge'. Research results are com- 
monly accessible but sometimes they are payable, especially if some extra services are provided to a user. The general tendency is to make the state budget support activities connected with open science, especially in the part that supports science and education. It applies to activities undertaken by individual users to a lesser extent.

The development of the concept of open science will influence organizational and economic solutions for a national information system for science and technique. Based on the conclusions of the scientific conferences on Open Access issues (Budapest and Berlin ones), P. Suber (Suber, 2007) formulated a definition of the new initiative's frames: "Access to Open Access literature must be free of charge for all users who have access to the Internet. All applications that serve scholarly purposes, i.e. reading, saving on a computer hard disc, copying, disseminating, printing, searching and linking are allowed. The only limitation imposed on a user is correct citing and specifying who the authors are".

Can all the collections of scholarly information be commonly accessible? J. Ziman (2002) separated two types of science: academic and industrial ones. They have different objectives. What they have in common is the implementation of knowledge management processes. This is obtaining, developing and retaining knowledge, sharing knowledge and personalization and codification of knowledge. In general, there are no basic differences between the actions related to: preparing publications of scholarly research results, developing repositories of documents and the systems of searching for information.

Economic models of funding scholarly research and making them available are different. The American Institute of Health (NIH), which is the biggest institution that finances medical research in the USA, introduced a rule that all beneficiaries of the so-called 'grants' from the NIH funds should publish the results of their research in a reviewed, commonly available journal in a period of 12 months. This Open Access publication of the results of research financed by the NIH is mandatory; an adequate Act was passed by Congress and signed by the United States President, Barak Obama. However, the rule is not always implemented by the users in the most desirable way (that is full archive available as soon as possible, free of charge and without limitations). Some special limitations and conditions are often imposed to protect the interests of publishers.

Interesting conclusions in this area can be found in the reports on Open Access costs and benefits developed under the supervision of J. Houghton of Victoria University in Australia (Houghton, 2008, 2009). They compare three models from three different countries: Great Britain, DURF in Holland and DEFF in Denmark. According to the report, the biggest benefits are obtained from the Open Access model, in which the research institution or a party providing finance for the research pays for the authors' publications. Such publications are available on-line free of charge. In Denmark, the adoption of this model provides savings of 70 million euro, in Holland 133 million euro and in Great Britain 480 million euro.

World solutions analysis (Hollender, 2011) shows that the range of solutions acceptable for a building strategy is varied. Table 2 shows the strategy dependence only on two variables, i.e. on the coordination system which is a management system and a financial solution. We have selected two variables: a management system and a financial solution as those which have the biggest impact on the choice of an organizational form and a way of funding the project. 
Table 2. Proposals of strategies for the implementation of a National Information System for Science and Technique (Source: Author' own output)

\begin{tabular}{|l|c|c|}
\hline Management system & $\begin{array}{l}\text { State budget finances the } \\
\text { System }\end{array}$ & $\begin{array}{l}\text { All user are charged for us- } \\
\text { ing the System }\end{array}$ \\
\hline $\begin{array}{l}\text { Centralized system of coor- } \\
\text { dination }\end{array}$ & Strategy I & Strategy III \\
\hline $\begin{array}{l}\text { Decentralized system of co- } \\
\text { ordination }\end{array}$ & Strategy II & Strategy IV \\
\hline
\end{tabular}

In practice, we deal with many other variants of the strategy to build the National Information System for Science and Technique. In the time of high demand for scientific works and a simultaneous post-crisis situation in the country, we have many dilemmas. In practice, it is difficult to use one strategy. Most often, hybrid strategies are used. Most institutions use various variants of strategy I (centralization and state budget funding in various forms) - as shown in table 2. But what strategy should be recommended for a particular country, e.g. Poland, in the existing conditions?

Of course, to make a decision it is necessary to analyze a profit and loss account and calculate outlays and effects of every of the four strategies presented above. However, a profit and loss account should not always be a ground for taking particular decisions. Very often, it plays the role of an economic advisor.

Strategy I: Centralized system; the state budget covers all the costs and some institutions take part in the project and provide the contents, and - via a central institution - purchase access to other databases of scholarly institutions and publishers. It is a very attractive solution but is it possible in the conditions of a particular country? The basic problem would be a big number of participating institutions. As a result, coordination of their participation and expectations can prove to be difficult. Finally, this solution is very expensive and difficult to implement. Due to the participation of the state Treasury, finance and coordination of actions can be secured on the central level.

Strategy II: dispersed management System. As the costs are covered by the State Treasury, this strategy is similar to the former one. However, the management system is decentralized, i.e. some actions are implemented on the level lower than the central one. In many countries, like in Poland, strategy II dominates and there are repositories managed this way. In Poland, they operate at Warsaw University (ICM) and in Poznan Computing Center. There is no centralized coordination system but the state budget finances most of the scientific projects. Solutions adopted in Open Access are a very strong support for the implementation of strategy II. The examples of Open Access solutions are characteristic for the present direction in the development of the strategy for supplying the SYNAT platform with the newest and most valuable scientific publications. The European Commission introduced a special regulation, the so-called Clause 39, which obliges institutions to make publications developed as European Union projects available in Open Access repositories. More specifically, they are repositories of the OpenAire program ordered by the European Commission and financed within the 7th Framework Programme. Warsaw University ICM is one of the major technological partners developing the OpenAire system portal (www.openaire.eu). Here, it is also necessary to take into account a suggestion that information about the present scholarly activity should appear in the place where research is done. It is necessary to forecast a dispersed character of the information system for science and technique and it can be expected that repositories will come into being at universities and other research institutions.

Strategy III: All users are charged for using the System. Elements of this strategy are found in Poland. It relates to scientific information collected by the Central Statistical Office. A fee is 
charged for the use of resources. Funding can also be provided by public-private partnership (PPP). About 680 corporations have been participating in providing finance for scientific research in Poland in the last 5 years.

Strategy IV: This strategy has many supporters. Participation in obtaining resources is based on market principles. The state does not incur considerable expenses on designing and using the System. It can be assumed that this is a route that strategy II will try to follow. At the beginning the State Treasury is a stakeholder of the information System for science and technique and later its stake in the undertaking is getting smaller. In Poland, like in most countries, the Ministry of Finance is in favor of this solution.

\section{Conclusion}

The relation between the system of education and the information system for science and technique is very strong. A good information system also means a good system of education and vice versa. A country with a good system of education is sure to have a high level of science. Countries which have an inefficient system of education certainly do not have a modern domestic information system for science and technique. The development of the coherent domestic system is a very difficult and expensive undertaking. That is why in many countries, like in Poland, the information system for science and technique is being implemented gradually. The SYNAT project is a stage in this process. It aims to create a universal, open, repositorial hosting and communications platform for network stores of knowledge for science, education and open society of knowledge linked to the adequate solutions in the world. Common access to information and knowledge in the field of science is an important stage in the development of every country.

A complexity of the issue makes it difficult to recommend one way of implementing a national information system in this field. Every country has specific conditions, both economic and political ones. In every country there are specific development priorities. That is why the presented strategies are outlined as a material for discussion.

Our task is to calculate an outlay necessary to provide a national information system for science and technique with equipment and propose organizational and legal ways of implementing the undertaking. One of the proposed routes for a scientific publication to get to the economy is creating small thriving advisory organizations. They would be responsible for supplying educational systems. In this area, there are various economic and organizational solutions possible. However, this issue goes beyond the framework of the presented article.

\section{References}

Adamick, J. (2010). Trends in large-scale subject repositories. D-Lib Magazine, 16(11/12). Retrieved from http://www.dlib.org/dlib/november10/11 contents.html

Arlt, C. (2006). Digital Right Management Systeme. Der Einsatz technischer Maßnahmen zur Schutz der digitalen Inhalte. C.H. Beck. München.

Björk, B., Roos, A., \& Lauri, M. (2009). Yearly volume and open access availability "Scientific journal publishing". Information Research, 14(1), March. Retrieved from http://informationr.net/ir/141/paper391.html

Castells, M. (1996). The rise of the network society. Oxford: Blackwell Publishers.

Crow, R. (2008). The case for institutional repositories: A SPARC position paper. Washington DC. Retrieved from http://www.arl.org/sparc/IR/ir.html

Dutta, S., \& Mia, I. (2012). The global information technology report 2010-2011 Transformations 2.0. INSEAD country/ rank within economy rank score income group, Retrieved from http://www3.weforum.org/docs/WEF_GITR_Report 2011.pdf 
Gibbons, S. (2004). Establishing an institutional repository. Library Technology Reports, 40(4), 1-168. Retrieved from https://publications.techsource.ala.org/products/archive.pl?article=2538

Hollender, H. (Ed.). (2011). Sprawozdanie z I etapu realizacji SYNAT. (Report from the first chase of the SYNAT Project) Uczelnia Łazarskiego. Warszawa.

Houghton, J., Rasmussen, B., Sheehan, S.; Oppenheim, C., Morris, A., Creaser, C., ... Gourlay, A. (2009). Economic implications of alternative scholarly publishing models: Exploring the costs and benefits. JISC EI-ASPM Project. Report to the Joint Information Systems Committee (JISC) (UK). CSES and Loughborough University. January

Houghton, J., \& Strategic Networks Group. (2008). Australian digital economy benchmarking. Report to the Department of Broadband, Communications and the Digital Economy by Strategic Network

King, D. (2010). An approach to open access author payment. D-Lib Magazine, 16(3 /4). Retrieved from http://www.dlib.org/dlib/march10/03contents.html

Kisielnicki, J. (2011). Docelowy model biznesowy dla instytucji eksploatujacych platformę SYNAT jako podstawy Krajowego Systemu Informacji Naukowo Technicznej KNSIT. (The business model for institutions operating on the platform SYNAT as a base of national system of scientific and technical information KNSIT) Uczelnia Łazarskiego. Warszawa.

Köhler, M., Arndt, H. W., \& Fetzer, T. (2008). Information society as seen by EU citizens. The Gallup Organization.

Laudon, K. C., \& Traver, C. G. (2011). E-commerce: Business, technology, society. Addison Wesley.

Niezgódka, M. (2009). Modele otwartego komunikowania w nauce i edukacji - perspektywy dla Polski. (Model of open communication in science and education - the prospects for Polish). In Public trust in science and industry-supported research and education. Materials from the PAN Conference. Warszawa.

Papadopoulou, P., Kanellis, P., \& Martakos, D. (2011). Social computing theory and practice: Interdisciplinary approaches. Hershey, PA, USA: IDG Global.

Safar, M., \& Mahdi, K. (2012). Social networking and community behavior modeling (Qualitative and quantitative measures). Hershey, PA, USA: Business Science Reference, IGI Global.

Soete, L., \& Weel, B. (2005). The economics of the digital society. Chelteham: Edward Elgar.

Suber, P. (2007). Open access overview. Open Access News. Retrieved from http://www.earlham.edu/ peters/fos/overview.htm

Swan, A. (2007). Open access and the progress of science. American Scientist, May-June, 197-199.

Szpringer, W. (2011) Koncepcja open access z perspektywy ekonomicznej analizy prawa - doświadczenia niemieckie. (The open access conception form the perspective of economic analysis of law - the German experience). E-mentor, 2(39). Retrieved from http://www.e-mentor.edu.pl/artykul/index/numer/39/id/820

Tansey, S. D. (2003). Business, information technology and society. London-New York: Routledge.

Turban, E., Lee, J., King, D., \& Chung H. M. (1999). Electronic commerce: A Managerial Perspective. New York: Prentice Hall.

Zacher, L. W. (1997). Problemy społeczeństwa informacyjnego. (The problems of information society). Wydawnictwo Wyższej Szkoły Przedsiębiorczości i Zarządzania im. Leona Koźmińskiego. Warszawa 


\section{Biography}

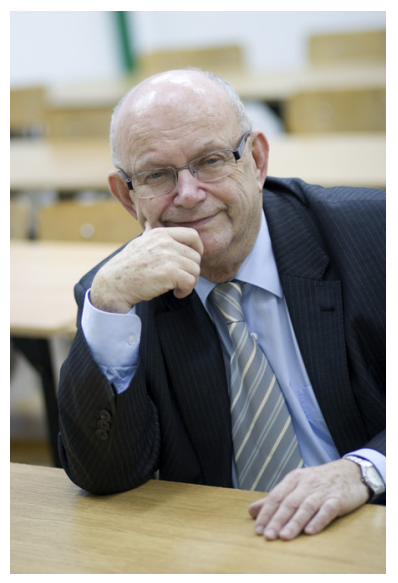

Jerzy Kisielnicki received a Ph.D. at the Warsaw School of Economics (S.G.P.i.S.) in 1969, and received a doctorate in 1969, and received a doctorate of Habilation in 1976 at the Warsaw University, Poland. He became a professor of economics in 1986, and he's been a full professor since 1992. Dr. Kisielnicki has been the head of the Department of Information Systems in Management and Faculty of Management at Warsaw University since 1972, and has been the head of the Department of Management at Marketing at the School of Economics (WSHiP) since 1995.

His interests are organization and management, systems analysis, management information systems, e-learning, process innovation (reengineering), strategic management, and transition systems organisation and management in market economy. He is a member Institute for Operations Research and the Management Science TIMS-ORSA. Dr. Kisielnicki is a member of the Board of Organization and Management in Polish Academy of Science and is the head of the Scientific Council of Polish Society of Systems Information. He has had about 220 publications. 